\title{
A Study on Energy and Condensation Performance Evaluation of Illuminance Sensor-Based Automatic Envelope with Built-in Type Blinds
}

\author{
Chang-Ho Choi ${ }^{1}$, Kyung-Soo Kim ${ }^{2}$, Han-Sol Lee ${ }^{3}$, Chang-Young Park ${ }^{4}$ and \\ Hyang-In Jang ${ }^{3 *}$ \\ ${ }^{1}$ Department of Architectural Engineering, Kwangwoon University, Seoul, Korea \\ 2,3,5 Institute of Green Building and New Technology, Mirae Environment Plan \\ Architects, Seoul, Korea \\ ${ }^{4}$ Mirae Environment Plan Architects, Seoul, Korea \\ ${ }^{1}$ Choi1967@kw.ac.kr, ${ }^{2} k k s @ m r p l a n . c o . k r,{ }^{3} h s l e e @ m r p l a n . c o . k r$, \\ ${ }^{4}$ cypark@mrplan.co.kr, ${ }^{5}$ hijang@mrplan.co.kr
}

\begin{abstract}
Studies on composite envelopes which combine windows and blinds are being performed based on a range of angles, in order to reduce the heating and cooling load through windows. However, it has been difficult to commercialize it due to the high cost of solar radiation sensors in the automatic control system. Therefore, this study adopted a triple pane window with built-in type blinds to propose a composite envelope with integrated blinds, and developed an illuminance sensor-based control algorithm. In addition, the triple pane window with built-in type blinds and algorithm proposed in this study was validated based on a simulation performance evaluation. The case settings for the performance evaluation are as follows: baseline double-hung window (Case 1), double-hung window according to configuration (Case 2, Case 3, Case 4), triple pane window (Case 5), low-E double-hung window with integrated blinds (Case 6), triple pane low-E window (Case 7), and the triple pane window with the algorithm proposed in this study (Case 8). The performance evaluation results are as follows. 1) Based on the results of calculating the cooling energy, Case 8 showed the lowest rate of cooling load compared to other cases. 2) Based on the results to derive the average daylight factor, Case 8 obtained a value of $1.51 \%$, meaning that it is more balanced than other cases. 3) Based on the results to derive the PMV, Case 8 was in the range of $-0.9 \sim 0.7$ throughout the year, which is closest to the thermal comfort range compared to other cases.4) The results of the performance evaluation regarding condensation indicated that condensation did not occur.
\end{abstract}

Keywords: Bult-in type blinds, illuminance sensor, Condensation, composite envelope, simulation performance evaluation

\section{Introduction}

\subsection{Background and Purpose of the Study}

In response to global climate change and amid growing demands for carbon emission reductions, it is becoming imperative to reduce energy consumption and emissions in order to achieve sustainable growth. According to the data released by the Energy Information Administration (US) in 2012, the heating and cooling

Received (April 8, 2018), Review Result (June 10, 2018), Accepted (June 18, 2018)

* Corresponding Author 
energy consumption in the building sector is $47.6 \%$, and this figure is reportedly increasing gradually[1]. In particular, according to the data announced at the 2012 Annual Report, heat loss from the building envelope is $69 \%$, and the energy loss rate through windows is reported to be $30 \%$ [2]. As a result, while development and research of products such as double-skin facades, triple pane windows, and low-E glass which increase the thermal transmittance performance, have been performed in order to reduce the energy loss through windows, there are only a few studies on the cooling load due to solar radiation inflow $[3,4]$.

The blind system is an envelope system installed in openings to block direct sunlight, thereby decreasing the cooling load during the summer, and reduces the heating load by blocking the heat transfer under the condition of equilibrium. Studies are being mainly conducted in an attempt to reduce the cooling and heating load by means of a composite envelope, mainly combined with windows[5,6,7]. Blind systems combined with system windows adopt control methods based on solar radiation, which enables accurate control but such methods are difficult to commercialize because of the high cost.

Despite the lack or absence of thermal insulation being the main cause of the occurrence of condensation in building envelopes, recently, the risk of condensation has increased in light of greater interest in methods of reducing energy consumption that have led to the use of high performance thermal insulation and air-tightening materials. This has resulted in greater differences between interior and exterior vapor pressures. According to the Secretariat of the Apartment Defect Dispute Mediation Committee, a government institution of South Korea, there were 8,859 accumulated cases of dispute mediation relating to condensation from 2010 to 2015 . During this time, the number of such cases has gradually risen each year and the proportion of cases related to condensation has amounted to approximately $14 \%$ of all defects[8]. In addition, an analysis of the reported cases of apartment defect repairs submitted to the Korea Consumer Agency indicated that cases related to condensation constituted $11 \%$ of all cases[9].

Therefore, this study adopts a triple pane window with built-in type blinds to devise a composite envelope, and developed an algorithm that can operate the blind slats based on illuminance sensors. Furthermore, through energy simulations-based performance evaluations, this study aims to verify the effectiveness and condensation performance of the illuminance sensor based automatic triple pane window system with built-in blinds proposed in this study.

\subsection{Procedures and Methods of the Study}

An illuminance sensor-based automatic triple pane window system with built-in type blinds was proposed and evaluated in this study following the procedures shown in Fig. 1. First, the feasibility of the illuminance sensor-based automatic triple pane window system with built-in type blinds proposed in this study was verified through the review of prior studies and blind systems. Second, the triple pane window with built-in type blinds was selected through a simulation evaluation based on blind installation location, and the operation algorithm based on illuminance sensors was proposed by considering the seasonal average illuminance values in Seoul, South Korea. Third, cases were set up to compare and analyze the performance, and the cooling and heating energy consumption, average daylight factor, and PMV (Predicted Mean Vote Index) were derived through simulation performance evaluation. Fourth, the effectiveness of the illuminance sensorbased automatic triple pane window system with built-in type blinds proposed in this study was verified by the uniformity performance and PMV results derived from the cooling and heating load and average daylight factor. In addition, the performance of the developed product against condensation was verified through simulations undertaken to evaluate condensation performance. 


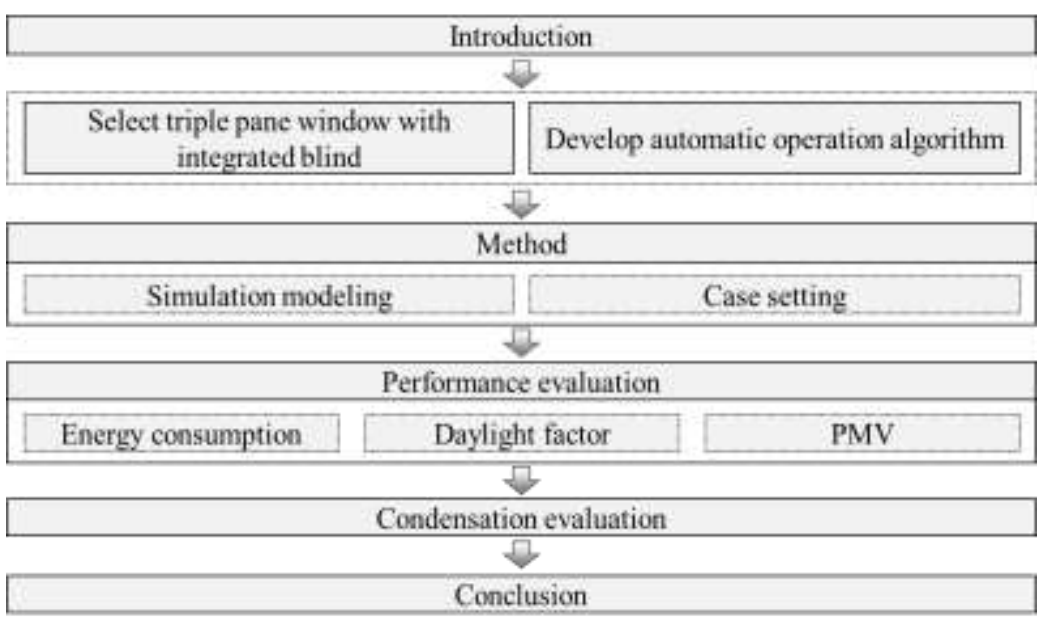

Figure 1. Procedures of the Study

\subsection{Consideration and Review of Prior Studies on Blind Control Systems}

As shown in Table 1, prior studies on window systems with built-in type blinds to reduce the cooling and heating load in openings were mainly conducted based on the control of solar radiation sensors. Although the advantage of accurate blind slat control is superior when using solar radiation sensors, it is difficult to commercialize and its use is minimal due to the high cost. Therefore, this study proposes a blind slat angle control algorithm based on illuminance sensors, which are less expensive than solar radiation sensors, to solve the commercialization problem.

Table 1. Consideration of Prior Studies

\begin{tabular}{|c|c|c|c|}
\hline Title & Author & $\begin{array}{l}\text { Sensor } \\
\text { type }\end{array}$ & $\begin{array}{l}\text { Illuminance } \\
\text { sensor }\end{array}$ \\
\hline $\begin{array}{c}\text { Study on Energy Performance And } \\
\text { Economic Evaluation of Windows system } \\
\text { with Built-in Type Blinds [10] }\end{array}$ & $\begin{array}{l}\text { W. H. Joe } \\
\quad \text { et al. }\end{array}$ & $\begin{array}{l}\text { Solar } \\
\text { radiation }\end{array}$ & $\mathrm{x}$ \\
\hline $\begin{array}{c}\text { Energy Performance Evaluation of } \\
\text { Apartment Building in Case of Applying a } \\
\text { Blind Integrated Window System [11] }\end{array}$ & $\begin{array}{l}\text { G. S. Choi } \\
\text { et al. }\end{array}$ & $\begin{array}{c}\text { Solar } \\
\text { radiation }\end{array}$ & $\mathrm{x}$ \\
\hline $\begin{array}{c}\text { Development \& Verification of the Solar } \\
\text { Control Window Appropriate for the Climate } \\
\text { Characteristics of Vietnam [12] }\end{array}$ & $\begin{array}{l}\text { K. J. Cho } \\
\text { et al. }\end{array}$ & $\begin{array}{c}\text { Solar } \\
\text { radiation }\end{array}$ & $\mathrm{x}$ \\
\hline $\begin{array}{l}\text { Effect of installing a venetian blind to a glass } \\
\text { window on human thermal comfort [13] }\end{array}$ & $\begin{array}{l}\text { N. hamporn } \\
\text { et al. }\end{array}$ & $\begin{array}{c}\text { Solar } \\
\text { radiation }\end{array}$ & $\mathrm{X}$ \\
\hline
\end{tabular}

\subsection{Blind System Observation for Slat Control Settings}

Blind systems are installed in windows and openings that are exposed to sunlight to block direct sunlight. It blocks the cooling load by blocking the solar radiation from entering the room during the summer, and reduces the heating load by blocking the heat transfer phenomenon caused by the temperature difference in the winter. The Venetian type blind is a blind system that is capable of adjusting the solar radiation flowing into the room through controlling the slat angle, and is selected as the blind in the window system with built-in blinds proposed in this study. The Venetian blind system controls the amount of light emitted into the room according to the blind slat angle, reflectivity, height, and 
width, as shown in Table 2, and considering prior studies, the blind slat angles proposed in this study were set to $30^{\circ}, 60^{\circ}, 90^{\circ}$, and $135^{\circ}[14]$.

Table 2. Blind Concept

\begin{tabular}{c|c|c|c}
\hline \multicolumn{2}{c|}{ Blind concept } \\
\hline Outside
\end{tabular}

\section{Proposal of Illuminance Sensor-Based Automatic Triple Pane Window System with Built-In Type Blinds}

\subsection{Simulation Analysis According to Blind Installation Location}

In this study, prior to proposing the illuminance sensor-based automatic triple pane window system with built-in blinds, the cooling and heating energy according to the blind installation location were compared and analyzed through a performance evaluation. The settings and results of the performance evaluation are as shown in Table 3, and the case settings were configured as no awning, internal awning type, external awning type, and cavity awning type. The performance evaluation period was set as winter (07:00 18:00), summer (18:00 07:00), and in-between seasons (07:00 18:00), and the blind slat angle was fixed at $45^{\circ}$ for performance evaluation. As a result of the simulation performance according to the blind location, compared to the case with no awning, the internal awning type, external awning type, and cavity awning type showed $8.59 \%, 19.23 \%$, and $15.61 \%$, respectively. The analysis is as follows.

Although the internal awning type was more effective in blocking sunlight compared to the case with no awning, the solar radiation heat reaches the inner glass window and thus increases the indoor heat. Although the external awning type has the largest solar radiation blocking effect, it is difficult to maintain and there is a great risk of damage due to weather events or other disasters. The cavity awning type shows a lower energy reduction performance than the external awning type, but there is less concern about damage and deformation, and it also has the advantage of being convenient to maintain. Therefore, the illuminance sensor-based automatic triple pane window system with builtin blinds proposed in this study was configured with the cavity internal awning type that has low risk of damage and a good energy reduction performance. 
Table 3. Performance Evaluation Environment Settings and Results by blind Location

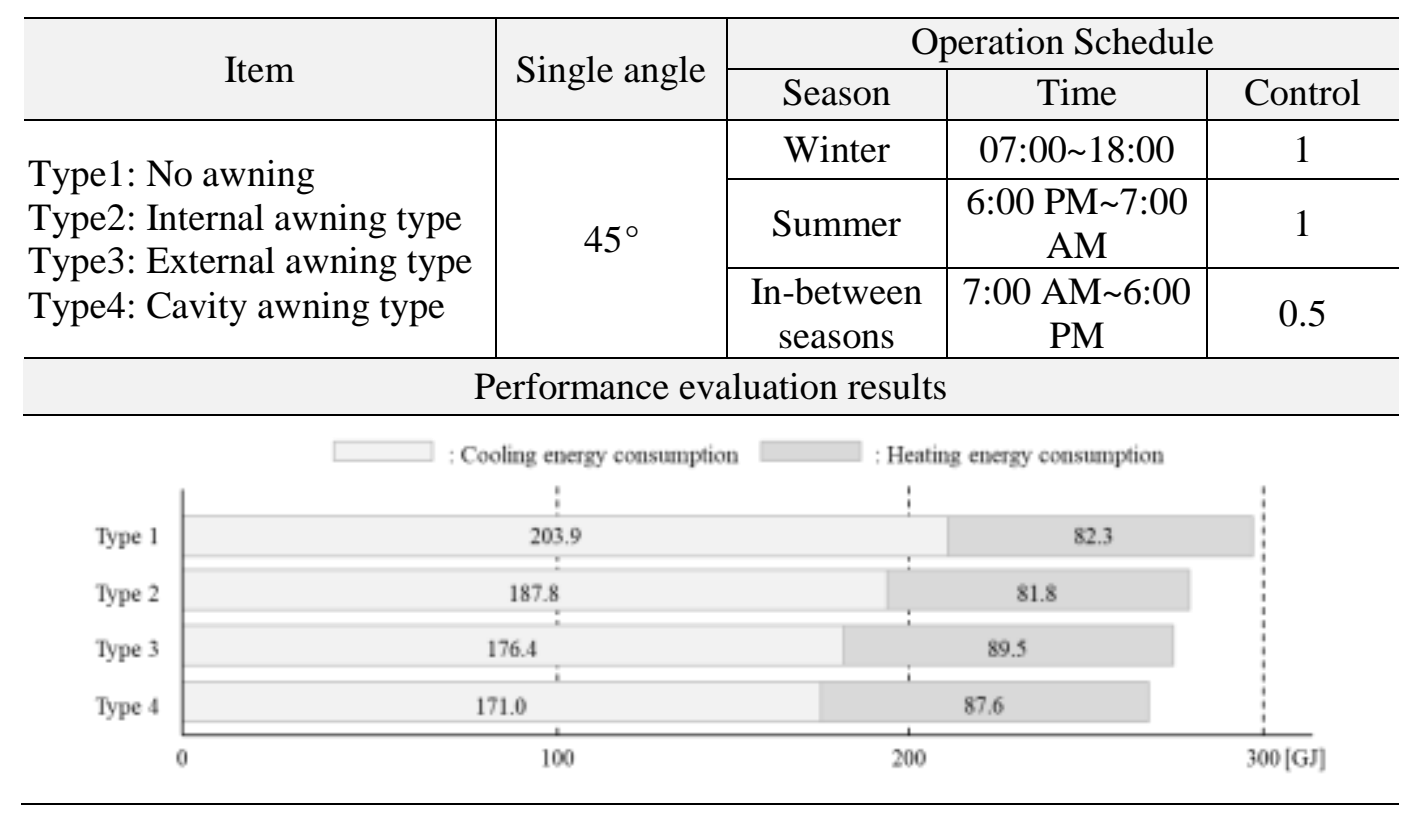

\subsection{Triple Pane Window with Built-In Type Blinds Setting}

In order to clearly analyze the illuminance sensor-based blind slat control performance of the illuminance sensor-based automatic triple pane window system with built-in blinds proposed in this study, as shown in Figure 2, a triple pane window with low thermal transmittance and which allows for cavity built-in blinds to be installed was selected among currently available windows for the analysis. The triple pane window product is a system window with Company A's thermal bridge blocking agent applied, which maximizes the insulation effect by setting the thickness of the intermediate air layer to $25 \mathrm{~mm}$, which determines the heat insulation performance of the window, and is equipped with Low-E triple glass with a thermal transmittance of $1.025 \mathrm{~W} / \mathrm{m}^{2} \mathrm{~K}$ (5T Low-e Clear + Argon $12 \mathrm{~mm}+5 \mathrm{~T}$ Clear + Argon $25 \mathrm{~mm}+5 \mathrm{~T}$ Low-e Clear). In addition, the UFrame of the frame is $2.305 \mathrm{~W} / \mathrm{m}^{2} \mathrm{~K}$, which is superior to other products. The illuminance sensor-based automatic triple pane window system with built-in blinds module proposed in this study can be controlled automatically, and the slat angle can be controlled by external illuminance. In addition, the blind slat can randomly operate up and down to secure the visibility of the user.

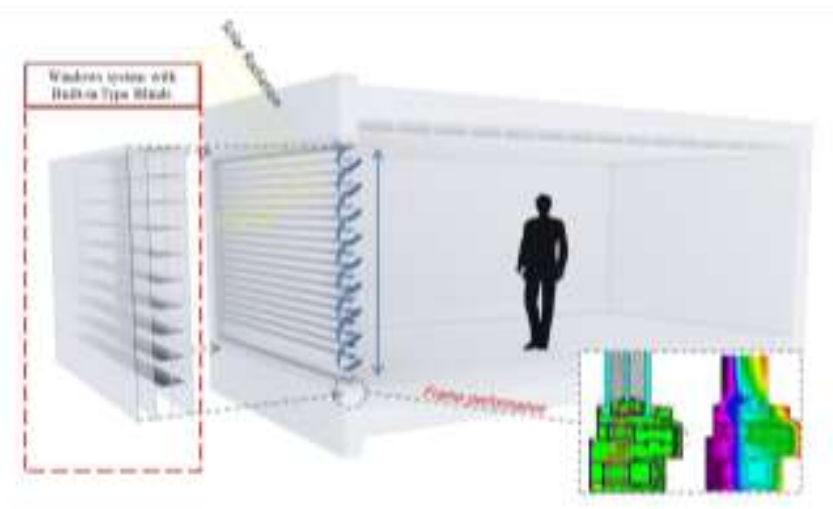

Figure 2. Triple Pane Window System with Built-In Type Blinds Module 


\subsection{Illuminance Sensor-Based Automatic Triple Pane Window System with Built-In Type Blinds Algorithm Proposal}

According to prior studies, the blind slat angle is generally controlled by solar radiation, but it is difficult to commercialize due to the high cost of the solar radiation sensor. Therefore, this study proposes slat angle control through sunlight illuminance based on low-cost illuminance sensors. In order to derive the automatic control algorithm, the standard meteorological data of Seoul, South Korea was analyzed using the Energyplus simulation tool and the correlation between the solar radiation and illuminance was derived. The results are shown in Figure 3.

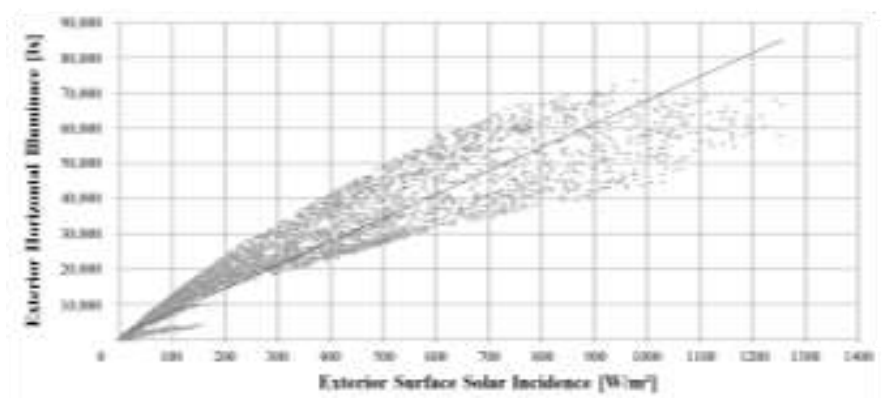

\section{Figure 3. Correlation between Horizontal Solar Radiation and External Illuminance}

The correlation between insolation and illuminance was not exactly identical but a trend line showing a similar pattern was derived and in order to concentrate on the blind slat opening and blocking algorithm, as shown in Figure 4. The boundary conditions were selected through the sky clearness factor from the meteorological data of Seoul for one year. The sky clearness factor indicates the degree of cloudiness in the atmosphere due to the increase in the amount of clouds as the coefficient increases, and the maximum external illuminance at the point of 6 or more, which is the mid-point of the clearness factor, is 20,000 $1 x[15]$.

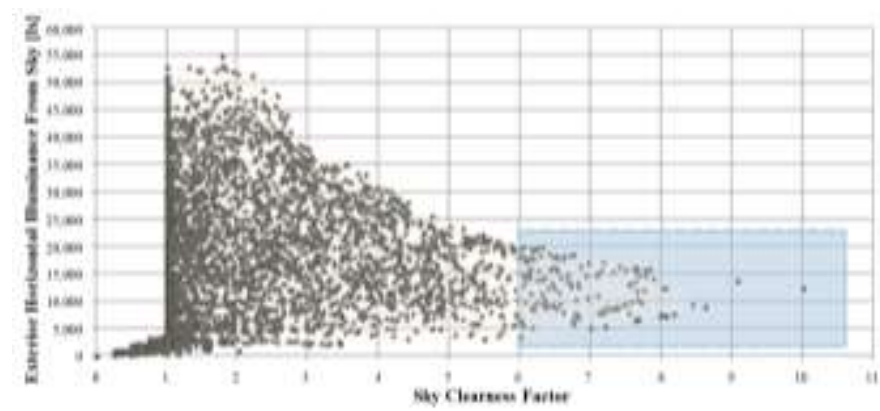

Figure 4. Correlation between Sky Clearness Factor and External
Illuminance

In this study, the automatic control algorithm was proposed with a focus on blocking solar radiation to reduce the cooling load, and Table 4 shows the slat angle control algorithm according to the external illuminance. The automatic control algorithm was developed to completely block the slat in clear sky conditions with a maximum external illuminance of more than 20,000 lx, and when it is 20,000 lx or lower, it can be controlled to $0^{\circ}, 22.5^{\circ}, 45^{\circ}, 67.5^{\circ}$, and $90^{\circ}$ depending on the illuminance in 5 levels. However, the automatic control algorithm was configured to detect the illuminance in the room to reflect the indoor influence caused by solar radiation, and the performance evaluation was performed by setting the indoor 
illuminance sensor detection algorithm to completely block the slat for conditions over 12,000 lx and setting the illuminance at level 5 for conditions below 12,000 lx.

Table 4. Slat Angle Control Commercialization Algorithm According to External Illuminance

\begin{tabular}{c|c|c|c}
\hline Level & $\begin{array}{c}\text { External illuminance } \\
\text { sensor detection }\end{array}$ & $\begin{array}{c}\text { Indoor illuminance } \\
\text { sensor detection }\end{array}$ & Slat angle control \\
\hline 1 & $0 \sim 5999 \mathrm{Lux}$ & 0 2999Lux & 0 \\
\hline 2 & 6000 9999Lux & 3000 5999Lux & 22.5 \\
\hline 3 & $10000 \sim 14999 \mathrm{Lux}$ & 6000 8999Lux & 45 \\
\hline 4 & $15000 \sim 19999 \mathrm{Lux}$ & 9000 11999Lux & 67.5 \\
\hline 5 & 20000Lux & 12000Lux & 90 \\
\hline
\end{tabular}

\section{Performance Evaluation Method and Results}

\subsection{Performance Evaluation Environment Settings}

Designbuilder, which is a graphic user interface based on Energyplus, was selected as the performance evaluation program in this study. EnergyPlus is not only capable of inputting items related to windows and blinds, but also has high accuracy in the analysis of solar radiation, surface radiation and convection, and heat transfer from the building envelope. When it is difficult for the user to input the exact performance parameters, Designbuilder is capable of performing an energy simulation analysis by defining the window with the SHGC (Solar Heat Gain Coefficient), VT (Visual Light Transmission), and thermal transmittance (U-value). However, the accuracy of the analysis is low in this case, and the performance may be overestimated depending on the input status of the frame performance of the window.

Table 5 and 6 show the environment settings for the performance evaluation of the illuminance sensor-based automatic triple pane window system with built-in blinds proposed in this study. The model to be analyzed was set as a business building. As there is no standard building data for simulation in Korea, the analysis was performed on an actual facility that is 14 floors above ground, with a total floor area of 5,669.02 $\mathrm{m}^{2}$. In addition, zoning according to space was divided into a large office, small office, restroom, and additional space, and simulation input conditions were set according to the use characteristics of the corresponding space. The meteorological data used for the simulation evaluation were 10 years of temperature data (2000-2009) and 20 years of solar radiation data (1991-2010) from the standard weather data of Seoul in EPW format based on Meteonorm7.0. However, infiltration and device heating were assumed to be constant regardless of time.

Table 5. Simulation Environment Settings for Performance Evaluation

\begin{tabular}{c|c}
\hline & Meteorological data \\
\hline Site location & $426.07 \mathrm{~m}^{2}$ \\
\hline Building area & $5669.02 \mathrm{~m}^{2}$ \\
\hline Total area & ASHRAE 90.1 Occupancy, Equipment, Lighting - Office \\
\hline Schedule & $117 \mathrm{~W} /$ person \\
\hline Body calorific value & $0.2 \mathrm{ACH}$ \\
\hline Infiltration & $10 \ell / \mathrm{sec} \cdot$ person \\
\hline
\end{tabular}




\begin{tabular}{c|c|c}
\hline Ventilation & \multicolumn{2}{c}{ Ideal Load Air System } \\
\hline HVAC & \multicolumn{2}{|c}{ Seoul, Korea (.epw) } \\
\hline \multicolumn{3}{c|}{ Simulation overview } \\
\hline
\end{tabular}

Table 6. Simulation Input Conditions by Zone

\begin{tabular}{c|c|c|c|c|c|c|c}
\hline Usage & $\begin{array}{c}\text { Air } \\
\text { conditioning } \\
\text { hours }\end{array}$ & Usage hours & $\begin{array}{c}\text { Heating } \\
\left({ }^{\circ} \mathrm{C}\right)\end{array}$ & $\begin{array}{c}\text { Cooling } \\
\left({ }^{\circ} \mathrm{C}\right)\end{array}$ & $\begin{array}{c}\text { Occupancy } \\
\text { density } \\
\left(\text { people/m } \mathrm{m}^{2}\right)\end{array}$ & $\begin{array}{c}\text { Device Outdoor air } \\
\text { heating } \\
(\mathrm{W})\end{array}$ & $\begin{array}{c}\left.\mathrm{W} / \mathrm{L} / \mathrm{sec} \cdot \mathrm{m}^{2}\right) \\
\text { intake }\end{array}$ \\
\hline Large office & $07: 00-18: 00$ & $07: 00-18: 00$ & 20 & 26 & 0.11 & 15 & 1.67 \\
\hline Small office & $\begin{array}{c}8: 00 \mathrm{AM}- \\
18: 00\end{array}$ & $\begin{array}{c}8: 00 \mathrm{AM}- \\
18: 00\end{array}$ & 18 & 25 & 0.05 & 5 & 1.11 \\
\hline Additional & $\begin{array}{c}8: 00 \mathrm{AM}- \\
18: 00\end{array}$ & $\begin{array}{c}8: 00 \mathrm{AM}- \\
18: 00\end{array}$ & 20 & 23 & 0.12 & 1.9 & 0.042 \\
\hline Restroom & $\begin{array}{c}8: 00 \mathrm{AM}- \\
18: 00\end{array}$ & $\begin{array}{c}8: 00 \mathrm{AM}- \\
18: 00\end{array}$ & 20 & 25 & 0.11 & 5.5 & 4.167 \\
\hline
\end{tabular}

The condensation performance evaluation of the illuminance sensor-based automatic triple pane window system proposed in this study was analyzed using Physibel-Trisco. Physibel-Trisco is an ISO 10211 based simulation program that is capable of conducting steady state thermal analysis regarding 3D heat exchanges, condensation analysis and heat transmittance calculations[16]. The boundary conditions for the simulation, as presented in Table 7, were presumed to include an outdoor temperature of $0{ }^{\circ} \mathrm{C}$, indoor temperature of $21^{\circ} \mathrm{C}$ and relative humidity of $50 \%$. The condensation performance analysis was undertaken upon setting the heat conductivity of the materials to $1.000 \mathrm{~W} / \mathrm{mK}$ for clear glass, $0.850 \mathrm{~W} / \mathrm{mK}$ for Low -e glass and $0.040 \mathrm{~W} / \mathrm{mK}$ for the Blind.

Table 8. Simulation Environment Settings for Condensation Evaluation

\begin{tabular}{|c|c|c|c|}
\hline \multicolumn{3}{|c|}{ Simulation overview } & Modeling \\
\hline \multirow{3}{*}{$\begin{array}{l}\text { Environmental } \\
\text { condition }\end{array}$} & External Temp. & $0{ }^{\circ} \mathrm{C}$ & \\
\hline & Internal Temp. & $21^{\circ} \mathrm{C}$ & \\
\hline & Internal R.H. & $50 \%$ & \\
\hline \multirow{3}{*}{$\begin{array}{c}\text { Thermal } \\
\text { Conductivity by } \\
\text { Material }\end{array}$} & Clear glass & $1.000 \mathrm{~W} / \mathrm{mK}$ & \\
\hline & Low-e glass & $0.850 \mathrm{~W} / \mathrm{mK}$ & \\
\hline & Blind & $0.040 \mathrm{~W} / \mathrm{mK}$ & \\
\hline
\end{tabular}

\subsection{Performance Evaluation Method}

In order to evaluate the simulation performance of the illuminance sensor-based automatic triple pane window system with built-in blinds proposed in this study, as 
shown in Table 8 , an energy performance evaluation and condensation performance evaluation was performed by selecting similar products that are most commonly used and developed in South Korea. The performance of a total of 8 cases including the product proposed in this study, were compared and analyzed. The case settings for performance evaluation are as follows: baseline double-hung window (Case 1), low-E double-hung window (Case 2), triple low-E double-hung window (Case 3), vacuum glass double-hung window (Case 4), triple pane window (Case 5), low-E double-hung window with integrated blinds (Case 6), triple pane low-E window (Case 7), and the triple pane window with the algorithm proposed in this study (Case 8). However, the thermal transmittance of all window frames other than the Baseline window is the same as the final product. The performance evaluation method of the illuminance sensor based automatic triple pane window system with built-in blinds proposed in this study is as follows.

First, the cooling and heating energy were derived through simulation analysis through DesignBuilder, in order to verify the effectiveness of the energy reduction performance of the illuminance sensor-based automatic triple pane window system with built-in blinds proposed in this study. The amount of cooling and heating energy used was derived by setting the office facility usage time to 10 hours (08:00 $\sim$ 18:00).

Second, this study performed a daylight analysis on the 8 cases through daylighting simulation analysis via DesignBuilder, and the uniformity ratio evaluation was conducted by deriving the average daylight factor, minimum daylight factor, maximum daylight factor, minimum illuminance, and maximum illuminance of each case.

Third, in order to evaluate the human comfort requirement, this study derived a comfort zone of $-0.5 \square+0.5$ by reflecting the temperature[17], humidity, air velocity, average radiation temperature, amount of clothing, and amount of activity on the PMV, which is a representative thermal comfort index, and performed a comparative analysis between the developed window and similar windows at natural room temperature (non-air conditioned) in the case building.

Fourth, to verify the condensation performance of the proposed triple-pane window system in this study, the surface temperatures of the window system were calculated by analyzing the simulations from Physibel-Trsico. Upon referencing the 'Design Standards for the Prevention of Condensation in Multi-Unit Residences,' the locations at which the surface temperatures were calculated for the evaluation of window condensation were set to include the center of the glass pane as shown in Fig. 5 a) and the four corners of the glass pane[18]. Occurrences of condensation were determined by the dew point temperature of the psychrometric chart as shown in Fig. 5 b). This study, however, was limited in that the condensation evaluation concerned only the window panes and did not evaluate condensation on the window frames.

Table 8. Case Setting Performance Evaluation

\begin{tabular}{|c|c|c|c|c|c|c|c|}
\hline Case & \multicolumn{2}{|c|}{ Window } & Glass composition & Blind & $\mathrm{Ug}$ & Uf & SHGC \\
\hline 1 & $\begin{array}{c}\text { Baselin } \\
\mathrm{e}\end{array}$ & $\begin{array}{c}\text { Transparent } \\
\text { double-hung }\end{array}$ & $\begin{array}{c}\text { 6T Clear+Air } \\
\text { 16mm+6T Clear }\end{array}$ & $\mathrm{X}$ & 2.676 & 4.20 & 0.701 \\
\hline 2 & \multirow{3}{*}{$\begin{array}{l}\text { Double- } \\
\text { hung } \\
\text { glass }\end{array}$} & $\begin{array}{c}\text { Low-E } \\
\text { double-hung }\end{array}$ & $\begin{array}{c}\text { 6T Clear+Air } \\
16 \mathrm{~mm}+6 \mathrm{~T} \text { Low-e }\end{array}$ & $\mathrm{X}$ & 1.872 & \multirow{3}{*}{1.48} & 0.47 \\
\hline 3 & & $\begin{array}{l}\text { Triple low-E } \\
\text { double-hung }\end{array}$ & $\begin{array}{c}\text { 6T Clear+Air } \\
\text { 16mm+6T Triple } \\
\text { Low-e }\end{array}$ & $X$ & 1.791 & & 0.417 \\
\hline 4 & & Vacuum glass & 6T Clear+Air & $\mathrm{X}$ & 0.7 & & 0.417 \\
\hline
\end{tabular}




\begin{tabular}{|c|c|c|c|c|c|c|}
\hline & & double-hung & $16 \mathrm{~mm}+6 \mathrm{~T}$ Vacuum & & & \\
\hline 5 & $\begin{array}{l}\text { Triple } \\
\text { pane } \\
\text { glass }\end{array}$ & $\begin{array}{l}\text { Low-E triple } \\
\text { pane double- } \\
\text { hung }\end{array}$ & $\begin{array}{c}\text { 6T Clear+Air } \\
\text { 16mm+6T Low-e } \\
+ \text { Air } 16 \mathrm{~mm}+6 \mathrm{~T} \\
\text { Low-e }\end{array}$ & $\mathrm{X}$ & 0.96 & 0.325 \\
\hline 6 & $\begin{array}{l}\text { Double- } \\
\text { hung } \\
\text { glass }\end{array}$ & $\begin{array}{c}\text { Low-E } \\
\text { double-hung }\end{array}$ & $\begin{array}{c}\text { 6T Clear+Air } \\
\text { 16mm+6T Low-e }\end{array}$ & $\begin{array}{c}\text { Roll shades } \\
\text { Transmittanc } \\
\text { e }-50 \% \\
\text { Reflectivity - } \\
50 \%\end{array}$ & 1.872 & 0.47 \\
\hline 7 & $\begin{array}{l}\text { Triple } \\
\text { pane } \\
\text { glass }\end{array}$ & $\begin{array}{l}\text { Low-E triple } \\
\text { pane double- } \\
\text { hung }\end{array}$ & $\begin{array}{c}\text { 6T Clear+Air } \\
\text { 16mm+6T Low-e } \\
+ \text { Air } 16 \mathrm{~mm}+6 \mathrm{~T} \\
\text { Low-e }\end{array}$ & $\begin{array}{c}\text { Roll shades } \\
\text { Transmittanc } \\
\text { e }-50 \% \\
\text { Reflectivity - } \\
50 \%\end{array}$ & 0.96 & 0.325 \\
\hline 8 & $\begin{array}{l}\text { Develop } \\
\quad \text { ed } \\
\text { product }\end{array}$ & $\begin{array}{l}\text { Low-E triple } \\
\text { pane double- } \\
\text { hung }\end{array}$ & $\begin{array}{c}\text { 5T Low-e +Argon } \\
12 \mathrm{~mm}+5 \mathrm{~T} \\
\text { Clear+Argon } \\
\text { 25mm+5T Low-e }\end{array}$ & $\begin{array}{l}\text { Built-in } \\
\text { blinds }\end{array}$ & 0.696 & 0.359 \\
\hline
\end{tabular}

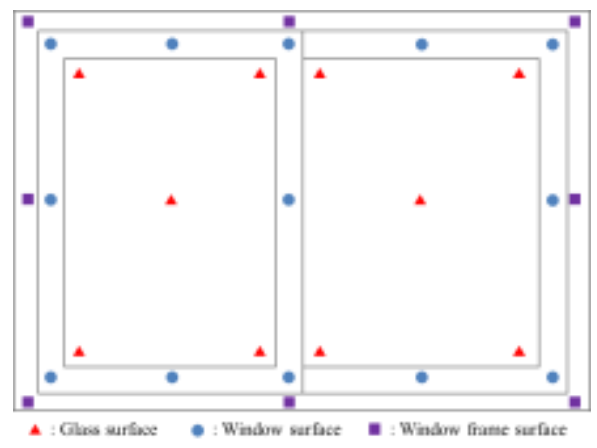

a) Measurement locations for the condensation performance evaluation

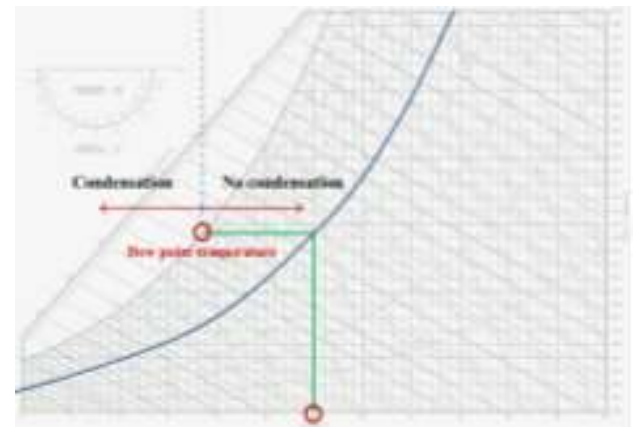

b) Occurrence/non-occurrence of condensation per the psychrometric chart

Figure 5. Condensation Verification Method

\subsection{Performance Evaluation Results and Analysis}

This study conducted a cooling and heating energy, average daylight factor, and PMV performance evaluation on the illuminance sensor-based automatic triple pane window system with built-in blinds as shown in Figure 6, Table 9, Table 10, Table 11, and Table 12, and the results are as follows.

First, for Case 2, Case 3, Case 4, Case 5, Case 6, Case 7, and Case 8, heating energy consumption increased by $7.0 \%, 45.7 \%, 25.0 \%, 1.5 \%, 41.3 \%, 6.3 \%$, and $30.3 \%$ compared to Baseline (Case 1), respectively, but cooling energy consumption decreased by $12.4 \%, 16.2 \%, 18.4 \%, 22.6 \%, 21.3 \%, 25.6 \%$, and $34.0 \%$, respectively. The analysis of the results indicates that when roll shades and blinds are installed on the window, the cooling energy is reduced by the decline of solar radiation inflow. In addition, when comparing the total amount of cooling and heating consumption, the product proposed in this study (Case 8) is effective for reducing the total amount of cooling and heating energy compared to other cases, even though the use of heating energy increased compared to the baseline.

Second, the average daylight factors of Case 1, Case 2, Case 3, Case 4, Case 5, Case 6, Case 7, and Case 8 were $4.11 \%, 2.75 \%, 2.54 \%, 2.54 \%, 1.65 \%, 2.76 \%$, and $1.51 \%$, respectively. The results show that the illuminance sensor-based automatic triple pane window system with built-in blinds (Case 8) has higher uniformity 
performance compared to other cases. This is considered to be a performance improvement according to the operation algorithm, and it is analyzed that the illuminance sensor based slat angle control in this study is effective.

Third, as a result of comparing the PMV of the illuminance sensor-based automatic triple pane window system with built-in blinds (Case 8) proposed in this study with other cases in natural room temperature (non-air conditioned) conditions, they were closer to the comfort zone in the ascending order of Case $4<$ Case $6<$ Case $7<$ Case $3<$ Case $2<$ Case $5<$ Case $1<$ Case 8 . Thus, the PMV of the developed product(Case 8 ) is shown to be effective as the results ranged between $0.9 \sim 0.7$ throughout the year, which is closest to the comfort zone, compared with other cases with similar windows.

Fourth, the condensation simulation results, as shown in Table 11, presented surface temperatures of $15.58^{\circ} \mathrm{C}$ at the center of the glass pane and $15.72{ }^{\circ} \mathrm{C}$ at the corners of the glass pane, which in general presented a rise in surface temperature values of the window system. Under the environmental conditions of this study which established the appropriate indoor temperature as $21^{\circ} \mathrm{C}$, relative humidity as $50 \%$ and dew point temperature as $10.22^{\circ} \mathrm{C}$, condensation was found to not occur in the triple pane window system proposed in this study.

Table 8. Cooling and Heating Energy Consumption

\begin{tabular}{c|c|c|c|c|c|c}
\hline \multirow{2}{*}{ Case } & \multicolumn{3}{|c|}{ Energy consumption $(\mathrm{kWh})$} & \multicolumn{3}{c}{ Percentage of change (\%) } \\
\cline { 2 - 7 } & Heating & Cooling & Total & Heating & Cooling & Total \\
\hline 1 & $119,359.31$ & $460,552.06$ & $579,911.37$ & - & - & - \\
\hline 2 & $127,770.60$ & $403,505.53$ & $531,276.13$ & $7.0 \%$ & $-12.4 \%$ & $-8.4 \%$ \\
\hline 3 & $138,116.92$ & $385,851.15$ & $523,968.07$ & $15.7 \%$ & $-16.2 \%$ & $-9.6 \%$ \\
\hline 4 & $89,552.46$ & $375,670.62$ & $465,223.08$ & $25.0 \%$ & $-18.4 \%$ & $-19.8 \%$ \\
\hline 5 & $117,524.34$ & $356,401.83$ & $473,926.17$ & $1.5 \%$ & $-22.6 \%$ & $-18.3 \%$ \\
\hline 6 & $168,649.71$ & $362,350.21$ & $530,999.92$ & $41.3 \%$ & $-21.3 \%$ & $-8.4 \%$ \\
\hline 7 & $126,822.25$ & $342,865.86$ & $469,688.11$ & $6.3 \%$ & $-25.6 \%$ & $-19.0 \%$ \\
\hline 8 & $155,503.82$ & $303,868.37$ & $459,372.19$ & $30.3 \%$ & $-34.0 \%$ & $-20.8 \%$ \\
\hline
\end{tabular}

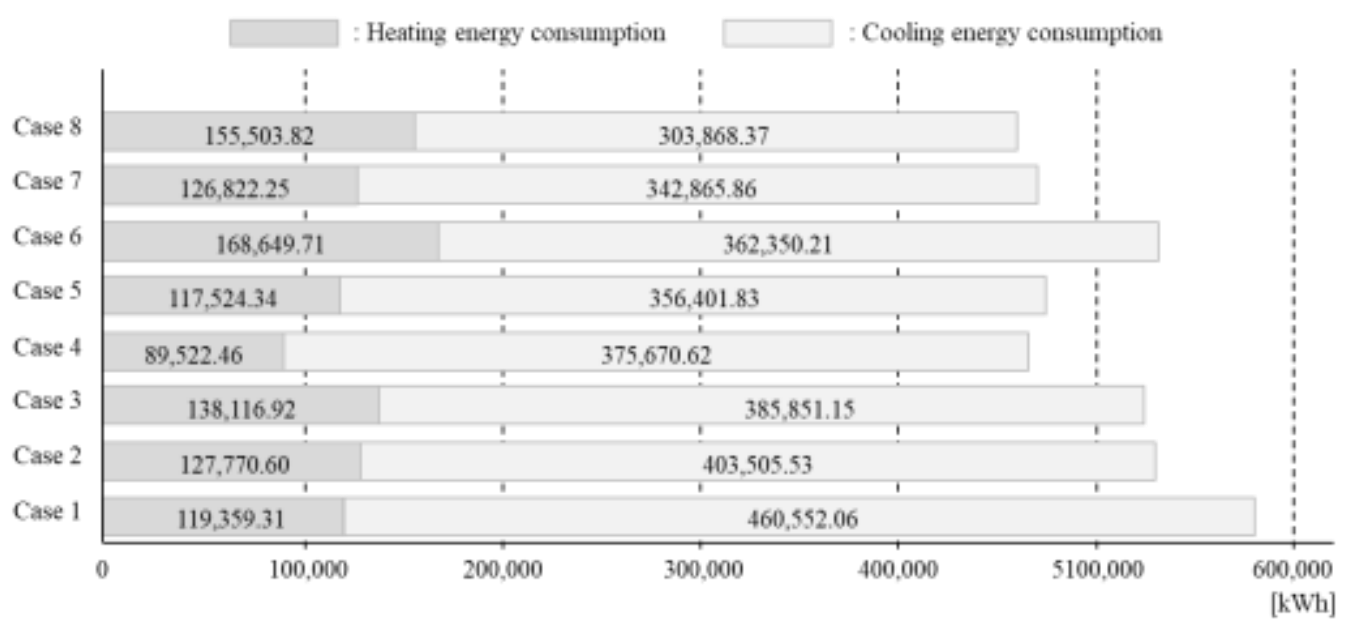

Figure 6. Performance Evaluation Results: Cooling and Heating Energy Consumption 
Table 10. Performance Evaluation Results: Average Daylight Factor

\begin{tabular}{|c|c|c|c|}
\hline $\begin{array}{c}\text { Illuminance } \\
\text { measurement result }\end{array}$ & Result value & $\begin{array}{c}\text { Illuminance } \\
\text { measurement result }\end{array}$ & Result value \\
\hline \multicolumn{2}{|c|}{ Case 1} & \multicolumn{2}{|c|}{ Case 5} \\
\hline$\pi$ & $\begin{array}{c}\text { Avg. daylight: } \\
4.11 \% \\
\text { Max. daylight: } \\
27.26 \% \\
\text { Max. illuminance: } \\
2732.25 \mathrm{~lx}\end{array}$ & $\pi$ & $\begin{array}{c}\text { Avg. daylight: } \\
1.65 \% \\
\text { Max. daylight: } \\
10.48 \% \\
\text { Max. illuminance: } \\
\text { 1049.14 lx }\end{array}$ \\
\hline \multicolumn{2}{|c|}{ Case 2} & \multicolumn{2}{|c|}{ Case 6} \\
\hline$\pi$ & $\begin{array}{c}\text { Avg. daylight: } \\
2.75 \% \\
\text { Max. daylight: } \\
17.80 \% \\
\text { Max. illuminance: } \\
1780.89 \mathrm{~lx}\end{array}$ & $\pi$ & $\begin{array}{c}\text { Avg. daylight: } \\
2.76 \% \\
\text { Max. daylight: } \\
18.97 \% \\
\text { Max. illuminance: } \\
1897.561 \mathrm{x}\end{array}$ \\
\hline \multicolumn{2}{|c|}{ Case 3} & \multicolumn{2}{|c|}{ Case 7} \\
\hline$\pi$ & $\begin{array}{c}\text { Avg. daylight: } \\
2.54 \% \\
\text { Max. daylight: } \\
16.16 \% \\
\text { Max. illuminance: } \\
1618.99 \text { lx }\end{array}$ & $\pi$ & $\begin{array}{c}\text { Avg. daylight: } \\
1.64 \% \\
\text { Max. daylight: } \\
10.39 \% \\
\text { Max. illuminance: } \\
1039.57 \text { lx }\end{array}$ \\
\hline \multicolumn{2}{|c|}{ Case 4} & \multicolumn{2}{|c|}{ Case 8} \\
\hline & $\begin{array}{c}\text { Avg. daylight: } \\
2.54 \% \\
\text { Max. daylight: } \\
\text { 16.04 \% } \\
\text { Max. illuminance: } \\
\text { 1607.14 lx }\end{array}$ & $\pi$ & $\begin{array}{c}\text { Avg. daylight: } \\
1.51 \% \\
\text { Max. daylight: } 9.56 \\
\% \\
\text { Max. illuminance: } \\
956.40 \text { lx }\end{array}$ \\
\hline
\end{tabular}

Table 11. Performance Evaluation Results: PMV

\begin{tabular}{c|c|c|c|c|c|c|c|c|c|c|c|c}
\hline Case & Jan & Feb & Mar & Apr & May & Jun & Jul & Aug & Sep & Oct & Nov & Dec \\
\hline 1 & 0.4 & 0.5 & 1.4 & 3.0 & 4.1 & 5.3 & 5.7 & 6.2 & 5.8 & 3.8 & 1.8 & 0.4 \\
\hline 2 & 0.4 & 0.6 & 1.5 & 3.1 & 4.2 & 5.6 & 6.2 & 6.7 & 6.2 & 4.0 & 2.1 & 0.6 \\
\hline 3 & 0.2 & 0.4 & 1.4 & 2.9 & 4.0 & 5.5 & 6.1 & 6.5 & 6.1 & 3.8 & 2.0 & 0.5 \\
\hline 4 & 1.4 & 1.7 & 2.5 & 4.4 & 5.6 & 7.1 & 7.8 & 8.2 & 7.8 & 5.2 & 3.4 & 1.8 \\
\hline 5 & 0.6 & 0.9 & 1.8 & 3.5 & 4.6 & 6.1 & 6.7 & 7.2 & 6.8 & 4.4 & 2.5 & 1.0 \\
\hline 6 & -0.3 & -0.1 & 0.9 & 2.2 & 3.3 & 4.7 & 5.4 & 5.8 & 5.3 & 3.3 & 1.4 & -0.1 \\
\hline 7 & 0.4 & 0.7 & 1.6 & 3.1 & 4.2 & 5.7 & 6.4 & 6.8 & 6.4 & 4.1 & 2.3 & 0.8 \\
\hline 8 & -0.9 & -0.8 & -0.4 & -0.4 & 0.2 & 0.3 & 0.4 & 0.4 & 0.3 & 0.7 & -0.4 & -0.8 \\
\hline
\end{tabular}


Table 12. Condensation Simulation Results of the Developed Window System

\begin{tabular}{c|c|c}
\hline Target part & Result value $\left({ }^{\circ} \mathrm{C}\right)$ & $\begin{array}{c}\text { Dew point temperature } \\
\text { value }\left({ }^{\circ} \mathrm{C}\right)\end{array}$ \\
\hline Center of glass & 15.58 & 10.22 \\
\hline Corner of glass & 15.72 & 10.22 \\
\hline
\end{tabular}

\section{Conclusion}

In this study, an illuminance sensor-based automatic triple pane window system with built-in blinds was proposed to the replace the high-cost solar radiation sensor, in order to secure the practical capability of blinds to bring about cooling and heating load reduction, and a performance evaluation was performed with similar products. The performance evaluation method was conducted using Designbuilder, an energy simulation program, and the condensation evaluation of the developed triple-pane window system of this study was undertaken using the steady state heat transfer analysis program, Physibel-Trisco. The conclusion is as follows.

First, the energy reduction performance was verified according to blind installation location to determine the installation location of the illuminance sensorbased automatic triple pane window system with built-in blinds developed in this study, and the cavity awning type was selected due to its low risk of damage and deformation. In addition, an algorithm was proposed to control the blind slat angle based on the illuminance sensor.

Second, for Case 2, Case 3, Case 4, Case 5, Case 6, Case 7, and Case 8, heating energy consumption increased by $7.0 \%, 45.7 \%, 25.0 \%, 1.5 \%, 41.3 \%, 6.3 \%$, and $30.3 \%$ compared to Baseline (Case 1), respectively, but cooling energy consumption decreased by $12.4 \%, 16.2 \%, 18.4 \%, 22.6 \%, 21.3 \%, 25.6 \%$, and $34.0 \%$, respectively. This indicates that the illuminance sensor-based automatic triple pane window system with built-in blinds proposed in this study demonstrates a good performance in terms of cooling load, and when comparing the total amount of cooling and heating energy consumption, it is capable of producing a better cooling and heating energy reduction performance compared to other cases, even though the use of heating energy increased.

Third, as a result of deriving the average daylight factor, Case 1, Case 2, Case 3, Case 4, Case 5, Case 6, Case 7, and Case 8 were $4.11 \%, 2.75 \%, 2.54 \%, 2.54 \%$, $1.65 \%, 2.76 \%$, and $1.51 \%$, respectively, and therefore the illuminance sensor-based automatic triple pane window system with built-in blinds (Case 8) proposed in this study showed a higher uniformity performance compared to other cases.

Fourth, as a result of deriving the PMV, the cases were closer to the comfort zone in the ascending order of Case $4<$ Case $6<$ Case $7<$ Case $3<$ Case $2<$ Case $5<$ Case $1<$ Case 8 , and the illuminance sensor-based automatic triple pane window system with built-in blinds (Case 8) proposed in this study showed results between $0.9 \sim 0.7$ throughout the year, which is closest to the comfort zone.

Fifth, there were no occurrences of condensation, although in general the surface temperature values of the window system were found to rise as presented in the results of the condensation performance evaluations.

The illuminance sensor based automatic triple pane window system with built-in blinds proposed in this study was found to not only reduce cooling loads but was also found to present effective expected average sensations of heat and coldness (PMV) and balanced performance compared to similar products in addition to presenting effective performance per the results of the condensation performance evaluation. However, this study is limited in that its performance evaluations were 
undertaken using a simulation program. Further studies that consider the feasibility of commercialization through test-bed performance evaluations are deemed necessary for the proposed products in the future.

\section{Acknowledgments}

This work was supported by the National Research Foundation of Korea(NRF) grant funded by the Korea government(MSIT) (No. 2017R1C1B2008728).

The work reported in this paper was conducted during the sabbatical year of Kwangwoon University in 2016.

\section{References}

[1] US Department of Energy, "2012 Buildings Energy Data Book”, USA, (2011).

[2] IEA, "2012 Annual Report”, (2012).

[3] S. S. Ghosh, P. K. Biswas and S. Neogi, "Thermal performance of solar cooker with special cover glass of low-e antimony doped indium oxide (IAO) coating”, Applied Thermal Engineering., vol. 113, (2017), pp. 103-111.

[4] S. H. Park, K. W. Kwon and J. Y. Sohn, "An analysis of heating and cooling loads by insulated shades and control method in an energy saving apartment", Korean Journal of Air-Conditioning and Refrigeration Engineering., vol. 22, no. 6, (2010), pp. 392-397.

[5] Y. Li, J. Darkwa and G. Kokogiannakis, "Heat transfer analysis of an integrated double skin façade and phase change material blind system", Building and Environment, vol. 125, (2017), pp. 111-121.

[6] M. V. Bavaresco and E. Ghisi, "Influence of user interaction with internal blinds on the energy efficiency of office buildings", Energy and Buildings, vol. 166, (2018), pp. 538-549.

[7] C. Carletti, F. Sciurpi, L. Pierangioli, F. Asdrubali, A. L. Pisello, F. Bianchi and C. Guattari, "Thermal and lighting effects of an external venetian blind: Experimental analysis in a full scale test room", Building and Environment, vol. 106, (2016), pp. 45-56.

[8] Ministry of Land, Infrastructure, and Transport, Office of Defect-Inspection Conflict Coordination Committee, (2015).

[9] Korea Consumer Agency, A defect repair report, (2016).

[10] W. H. Joe and N. G. Lim, "Study on Energy Performance and Economic Evaluation of Windows System with Built-in Type Blinds", Journal of the Korea Institute of Building Construction, vol. 10, no. 2, (2010), pp. 97-104.

[11] G. S. Choi and J. Y. Sohn, "Energy performance evaluation of apartment building in case of applying a blind integrated window system", Korean Journal of Air-Conditioning and Refrigeration Engineering, vol. 22, no. 7, (2010), pp. 429-435.

[12] K. J. Cho and D. W. Joe, "Development \& Verification of the Solar Control Window Appropriate for the Climate Characteristics of Vietnam", Proceedings of the architectural institute of Korea planning \& Design., vol. 37, no. 2, (2017), pp. 593-596.

[13] N. Khamporn and S. Chaiyapinunt, "Effect of installing a venetian blind to a glass window on human thermal comfort", Building and Environment, vol. 82, (2014), pp. 713-725.

[14] D. S. Hwang and K. H. Lee, "A Study on the Change of Indoor Thermal Environment According to the location of Blinds", Journal of Korean Solar Energy Society, vol. 13, no. 5, (2011), pp. 113-118.

[15] K. S. Kim, H. S. Lee, C. Y. Park and H. I. Jang, "Proposal and Performance Evaluation of Automatic Blind Algorithm Based on Illuminance Sensors", Asia-Pacific of Advanced Research in Electrical and Electronics Engineering., vol. 2, no. 1, (2018), pp. 7-12.

[16] Y. J. Cho, J. H. Kim and J. J. Yee, "Performance Evaluation of External Insulation Systems with Fire Resistance in Modular House", Conference of KIAEBS, (2012), pp. 164-167

[17] S. M. Oh, Y. R. Kim, J. H. Kim, S. L. Park and J. H. Kim, "Evaluation of Inside Surface Condensation in Window System of multi-residential houses: Focused on Temperature Difference Ratio(TDR)", Journal of SHURI, vol. 4, no. 2, (2014), pp. 39-46.

[18] W. Y. Yang, "Thermal Comfort Range of PMV for Koreans by Subjective Assessment in an Indoor Environmental Chamber", Journal of Korean Society of Living Environment System, vol. 24, no. 1 (2017), pp. 37-45. 